Johnson \& Wales University ScholarsArchive@JWU

Humanities Department Faculty Publications \&

Research

$4-2012$

\title{
The King's Best Highway: The Lost History of the Boston Post Road, the Route that Made America (review)
}

Michael R. Fein

Johnson \& Wales University - Providence, mfein@jwu.edu

Follow this and additional works at: https://scholarsarchive.jwu.edu/humanities_fac

Part of the Cultural History Commons, History of Science, Technology, and Medicine

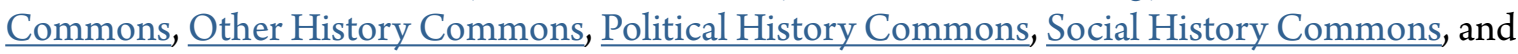
the United States History Commons

\section{Repository Citation}

Fein, Michael R., "The King's Best Highway: The Lost History of the Boston Post Road, the Route that Made America (review)" (2012). Humanities Department Faculty Publications \& Research. 43.

https://scholarsarchive.jwu.edu/humanities_fac/43 


\section{TECH NOL O G Y A N D C U LTURE}

longed for a just order that would recognize true men of talent. His loving descriptions of different technologies indicated great respect for the work of craftsmen, if not for the workers themselves. He believed that the scholar who understood natural transformation based on empirical investigation had superior insight to the speculative philosopher.

Craft work, in highly valued objects like porcelain and silk, was also a

APRIL

2012

VOL. 53 major focus of the imperial state. The Ming state ran imperial workshops, where craftsmen (a heritable status) produced objects for the emperor's court. These large enterprises grew to industrial scale when they found outlets to serve burgeoning private demand. Craftsmen traveled long distances to market their skills to consumers outside the state. Song linked his philosophy with the material support of the imperial order by focusing on crafts that had particular aesthetic, ritual, and moral significance. We do not learn much here about his attitudes toward popular and market demand for these products, but he did advocate consulting with merchants to improve official policy.

Song, however, avoided abstract philosophical speculation, so it takes especially close analysis to tease out his assumptions from his descriptions. Song's approach reflected an empirical point of view comparable in many respects to that of empiricists in early modern Europe: a respect for details, a willingness to modify classical theories in the light of experience, and even an interest in conducting experiments. This study gives a fascinating glimpse of the cultural background supporting sophisticated craftsmanship in imperial China, and stimulates important comparative insights on the related but distinct tracks of technological development in China and the West.

PETER C. PERDUE

Peter C. Perdue is professor of history at Yale University. He is the author of Exhausting the Earth: State and Peasant in Hunan, 1500-1850 (1987), China Marches West: The Qing Conquest of Central Eurasia (2005), and many articles on imperial Chinese social and economic development.

The King's Best Highway: The Lost History of the Boston Post Road, the Route that Made America.

By Eric Jaffe. New York: Scribner, 2010. Pp. ix+322. \$27.50.

There is much to admire in The King's Best Highway, Eric Jaffe's "lost history" of the Boston Post Road (BPR). In brisk style, Jaffe whisks the reader in a tour of the signal events that have unfolded along this old route ever since the age of early British settlement. He has a strong feel for gripping anecdotes and the rich characters - ranging from John Winthrop Jr. to P. T. Barnum-whose lives intersect the road in intriguing ways. While the tales 
are captivating, they never make clear precisely what about the road was "lost" to history, and what has now been found.

Targeting "American history buffs," Jaffe covers much familiar ground, although with concentrated attention to the peculiar twists and turns of the Boston-to-New York route. The notes section suggests a detailed examination of original correspondence and archival research, and the text provides a valuable account of historical actors, both well- and lesser-known. Benjamin Franklin and George Washington travel the road, as postmaster and Revolutionary War general, respectively. But we also meet John Oldham, one of the first Plymouth settlers to survey what became the "Ordinary Way" in the 1630s; William Goddard, a Providence printer who defied the Stamp Act in the 1770s; Albert Pope, who popularized bicycling in the 1880s; and Lester Barlow, who lobbied for federally funded expressways in the 1920s.

The book is at its best when it explores the people who continually reinvented the road, or found in it a different meaning than their forebears. The route has changed little over the centuries: indeed, Jaffe notes that the Boston-to-Springfield route of the 1770s is only a scant four miles longer than today's Interstate 90. But the stone and asphalt of the BPR turn out to be far more mercurial substances in Jaffe's hands. To the Wickquasgecks, the path was a trade route, facilitating exchange with neighboring tribes and the Dutch inhabitants of Manhattan. To settlers in Oldham's day, the "ordinary way" not only opened up inland colonial travel, it also conferred a sense of permanence to the towns that sprang up along its course. To Goddard and other publishers, the BPR was a "loop of information" that soon became a medium for revolution (p. 38). To Washington, the "King's Best Highway" was a conduit for revolutionary arms and armies. After the war, the BPR became a sign of national betterment, first as an improved route, then as the site of parallel railroad and streetcar lines. To Pope, Barlow, and other moderns, the road became synonymous with mobility, speed, and freedom. As the road moved on to "semiretirement" in the fastpaced interstate era, its stop-and-go traffic has left it in an "identity crisis": torn between nostalgia for the route's historic past and the bland repetition of endless Dunkin' Donuts storefronts (pp. 239, 244).

Given the shape-shifting nature of the road, it is no surprise that Jaffe leaves several avenues underexplored. In part this reflects his choice of an episodic approach over one that directly engages intersecting historiography. It also reflects the challenges of portraying the road itself as a driving force. For instance, Jaffe claims that the route had a critical impact on colonial cohesiveness. But on the eve of revolution, at a time when other elements of colonial culture were becoming more distinctly British, was the King's Best Highway an agent of Anglicization or Americanization? Jaffe also assigns the colonial-era BPR a place of prime importance in the nas- 
APRIL

2012

VOL. 53

cent American postal system. But did its presence alone spark a communication revolution, or did it require the political and administrative system put in place by Franklin and others after the Revolution? And much later, when the BPR (relocated as part of U.S. Route 1) gained fame as the nation's most heavily trafficked stretch of highway, was it the road itself that figured into its adoption as the nation's road standard, or was that the result of public works officials, such as Robert Moses, who used their experience navigating state highway politics to influence the direction of national transportation policy?

By marking regular increases in the route's efficiency and connectedness, the narrative sometimes drifts into a "march-of-progress" mode, which appears at odds with Jaffe's ultimate conclusion about the road's meaning for contemporary Americans. When the prospect of bicycle-and later automotive-travel arrives on the scene at the turn of the twentieth century, Jaffe describes this move as a victory for individual freedom over the control of monopolistic railroad magnates. It's hard to see why he spins this so positively, given what follows during the automotive age. The BPR becomes a "window" onto a series of cultural transformations that begins with bootlegging, moves through the devastation of urban renewal and the convulsion of the freeway revolts, and ends with the arrival of suburban sprawl and mega-chains (p. 202). By the close of the story-a history of "schizophrenia in asphalt," in Jaffe's words-he offers a tentative stab at what may have been the BPR's essential purpose: to provide the warm security of distinct, interlinked communities (p. 242). Given what we know about the level of coercion and conformity in Puritan towns and of the destruction of indigenous communities that allowed for the road's growth, this comes across as a shade too nostalgic. Yet it's hard to dispute the idea of the road as symbolic of something we have lost, through the devastation wreaked on historic New England cities by urban interstates, through the collapsing of time and space in the digital age, and through the transformations of the BPR's purpose. Roads once mobilized communities, and now they simply mobilize. Ultimately the BPR has been many things to many people, and, as The King's Best Highway testifies, it is also a mirror to ourselves. But perhaps the most important question posed by the book is one we lack a satisfying answer to: What does it say about Americans that we look to the highway_-with all that it conjures—and find our own reflection?

MICHAEL R. FEIN

Michael R. Fein is associate professor of history and Honors Program director at Johnson \& Wales University. He is the author of Paving the Way: New York Road Building and the American State, 1880-1956 (2008). 